\title{
Toward an understanding of risk factors for Binge Eating Disorder in black and white women: A community-based case-control study
}

\author{
R. H. Striegel-Moore \\ C. G. Fairburn \\ D. E. Wilfley \\ K. M. Pike \\ Follow this and additional works at: https://digitalcommons.fairfield.edu/education-facultypubs \\ Faith-Anne Dohm \\ Goiptylelght 2005 5 , ambridge University Press \\ Article available at publisher site: http://journals.cambridge.org/ \\ download.php?file=\%2FPSM\%2FPSM35_06\%2FS0033291704003435a.pdf\&code=15e6b10ca29eff469a5cdd4e \\ See next page for additional authors
}

\section{Peer Reviewed}

\section{Repository Citation}

Striegel-Moore, R. H.; Fairburn, C. G.; Wilfley, D. E.; Pike, K. M.; Dohm, Faith-Anne; and Kraemer, H. C., "Toward an understanding of risk factors for Binge Eating Disorder in black and white women: $\mathrm{A}$ community-based case-control study" (2005). GSEAP Faculty Publications. 26.

https://digitalcommons.fairfield.edu/education-facultypubs/26

\section{Published Citation}

Striegel-Moore, R. H., Fairburn, C. G., Wilfley, D. E., Pike, K. M., Dohm, F. A., \& Kraemer, H. C. (2005). Toward an understanding of risk factors for Binge Eating Disorder in black and white women: A community-based case-control study. Psychological Medicine, 35(6), 907-917.

This item has been accepted for inclusion in DigitalCommons@Fairfield by an authorized administrator of DigitalCommons@Fairfield. It is brought to you by DigitalCommons@Fairfield with permission from the rightsholder(s) and is protected by copyright and/or related rights. You are free to use this item in any way that is permitted by the copyright and related rights legislation that applies to your use. For other uses, you need to obtain permission from the rights-holder(s) directly, unless additional rights are indicated by a Creative Commons license in the record and/or on the work itself. For more information, please contact digitalcommons@fairfield.edu. 


\section{Authors}

R. H. Striegel-Moore, C. G. Fairburn, D. E. Wilfley, K. M. Pike, Faith-Anne Dohm, and H. C. Kraemer 


\title{
Toward an understanding of risk factors for binge-eating disorder in black and white women: a community-based case-control study
}

\author{
RUTH H. STRIEGEL-MOORE ${ }^{* *}$, CHRISTOPHER G. FAIRBUR ${ }^{2}$, \\ DENISE E. WILFLEY ${ }^{3}$, KATHLEEN M. PIKE ${ }^{4}$, FAITH-ANNE DOHM ${ }^{5}$ \\ AND HELENA C. KRAEMER ${ }^{6}$ \\ ${ }^{1}$ Department of Psychology, Wesleyan University, Middletown, CT, USA $;{ }^{2}$ Department of Psychiatry, \\ Warneford Hospital, Oxford University, Oxford, UK $;^{3}$ Department of Psychiatry, Washington University, \\ MO, USA $;{ }^{4}$ Department of Psychiatry, Columbia University, NY, USA $;{ }^{5}$ Graduate School of Education \\ $\&$ Allied Professions, Fairfield University, CT, USA; ${ }^{6}$ Department of Psychiatry and Behavioral Sciences, \\ Stanford University, CA, USA
}

\begin{abstract}
Background. This study sought to identify in white women risk factors specific to binge-eating disorder (BED) and for psychiatric disorders in general, and to compare black and white women on risk factors for BED.

Method. A case-control design was used. Participants were recruited from the community and included 162 women who met DSM-IV criteria for BED and two comparison groups of women with no history of clinically significant eating disorder symptoms. The comparison women were matched to BED women on age, education and ethnicity and divided into a healthy comparison (HC) group, who had no current psychiatric disorder, and a psychiatric comparison (PC) group, who had a diagnosis of a DSM-IV Axis I psychiatric disorder. The study sample size was determined by the group with the least members (PC), including 107 women with BED and 214 matched comparison women. A broad range of risk factors was assessed with a Risk Factor Interview and the Parental Bonding Instrument.
\end{abstract}

Results. No significant effects for ethnicity by diagnostic group were found. BED women reported higher exposure to childhood obesity, family overeating or binge-eating, family discord, and high parental demands than PC women. The combined BED and PC group scored significantly higher than the HC group on measures of negative affect, parental mood and substance disorders, perfectionism, separation from parents, and maternal problems with parenting.

Conclusions. These findings indicate that childhood obesity and familial eating problems are reliable specific risk factors for BED. Ethnicity does not appear to moderate risk for BED.

\section{INTRODUCTION}

Binge-eating disorder (BED) was introduced in the Diagnostic and Statistical Manual of Mental Disorders (4th edn) (DSM-IV) as a provisional

* Address for correspondence: Dr Ruth Striegel-Moore, Department of Psychology, Wesleyan University, 207 High Street, Middletown, CT 06459, USA.

(Email: rstriegel@wesleyan.edu) diagnosis in need of further study (APA, 1994). $\mathrm{BED}$ is defined by recurrent episodes of bingeeating that occur in the absence of the regular use of inappropriate compensatory behavior. Additional criteria include presence of behavioral indicators of loss of control over eating and distress over the binge-eating episodes.

A growing literature has documented the clinical significance of BED and there have been 
several controlled studies of its treatment (Carter et al. 2003; Wilfley et al. 2003; Wonderlick et al. 2003). Only one comprehensive risk factor study has been reported to date (Fairburn et al. 1998). Using a case-control design, it found that women with BED differed significantly from women without an eating disorder on measures of psychological characteristics (negative self-evaluation, premorbid depression) and rates of exposure to adverse familial or environmental experiences (e.g. childhood physical and sexual abuse, low parental affection, parental psychopathology). However, comparisons of women with BED and women with other (non-eating) mental disorders found no significant differences in exposure to these risk variables, suggesting that these are 'general' risk factors (i.e. associated with increased risk for a variety of psychiatric disorders). The study also identified variables that were significantly more common among women with BED compared with women with non-eating psychiatric disorders. These 'specific' risk factors included childhood obesity, family dieting, and social pressure about being overweight.

Because most studies in the eating disorder field include few or no non-white participants, little is known about BED in ethnic minority populations. Epidemiological studies suggest, however, that BED is found among a substantial number of ethnic minority females (Smith et al. 1998; Striegel-Moore et al. 2000, 2003; Johnson et al. 2001). Also, studies suggest that there may be different rates for eating disorders or eating-related symptomatology in ethnic minority females as compared with white females (Pike et al. 2001; Smolak \& Striegel-Moore, 2001). To address this gap, the New England Women's Health Project (NEWHP) was initiated to examine the clinical presentation of (Pike et al. 2001) and risk factors for BED in a community sample of black and white women. The NEWHP study was modeled after the Oxford risk factor study (Fairburn et al. 1998).

The present report describes the findings of this risk factor study. It sought: (1) to replicate in white women the findings concerning specific risk factors (history of childhood obesity; exposure to social pressure regarding weight; exposure to familial weight and eating disorders) and general risk factors (personal vulnerability characteristics such as negative affectivity, inadequate parenting, parental psychopathology); and (2) to compare black and white women on risk factors for the disorder. Regarding the possible effect of ethnicity we predicted that black and white women with BED would share risk factors with one exception. Specifically, we hypothesized that exposure to ethnic diversity (e.g. black women interacting frequently with white women) would be associated with an increased risk for the development of BED in black women. Ethnic group differences in the prevalence of eating disorders have been attributed in part to differences in exposure to cultural factors and social norms regarding body image and eating (Striegel-Moore \& Cachelin, 2001; Sanchez-Johnsen et al. 2004). For example, black women, on average, have been found to be less exposed to family dieting or social pressure about being overweight (Smolak \& Striegel-Moore, 2001), factors that were found to be specific risk factors for BED in the Oxford study (Fairburn et al. 1998). In contrast, for white women exposure to ethnic diversity (e.g. white women interacting frequently with black women) was hypothesized to be unrelated to risk for the development of BED.

\section{METHOD \\ Design}

A case-control design was used, recruiting women from the community who identified themselves as either white American or black American and, following a two-stage assessment to determine diagnostic status, assigning them to one of three groups: cases (i.e. women with BED) and two 'control' or comparison groups. The women in the comparison groups were individually matched to the women with BED on ethnicity, age (within 2 years) and education. Inclusion criteria for the healthy comparison (HC) group were absence of a history of clinically significant eating-disorder symptoms and no current psychiatric disorder. For the psychiatric comparison (PC) group, inclusion required presence of a current DSM-IV Axis I psychiatric disorder, but no history of clinically significant eating-disorder symptoms. While information regarding lifetime psychiatric diagnostic status was collected, the comparison groups were chosen based on the presence/absence of a current psychiatric diagnosis in order that our 
Table 1. Demographic information for all BED cases and for subsample used in the analyses

\begin{tabular}{|c|c|c|c|c|}
\hline & \multicolumn{2}{|c|}{ White } & \multicolumn{2}{|c|}{ Black } \\
\hline & $\begin{array}{l}\text { All cases } \\
(n=102)\end{array}$ & $\begin{array}{l}\text { Analyzed cases } \\
\quad(n=86)\end{array}$ & $\begin{array}{l}\text { All cases } \\
(n=60)\end{array}$ & $\begin{array}{c}\text { Analyzed cases } \\
(n=21)\end{array}$ \\
\hline Mean age (S.D.) & $31 \cdot 27(5 \cdot 60)$ & $31 \cdot 12(5 \cdot 66)$ & $30 \cdot 68(5 \cdot 95)$ & $30 \cdot 10(6 \cdot 46)$ \\
\hline Mean index age (S.D.) ${ }^{\mathrm{a}}$ & $14 \cdot 04(5 \cdot 50)$ & $14.06(5.08)$ & $18.57(8.51)$ & $15 \cdot 24(7 \cdot 05)$ \\
\hline Mean BMI (s.D.) ${ }^{\mathrm{b}}$ & $33 \cdot 35(10 \cdot 23)$ & $33 \cdot 04(10 \cdot 06)$ & $36 \cdot 74(9 \cdot 29)$ & $37 \cdot 14(9 \cdot 33)$ \\
\hline \multicolumn{5}{|l|}{ Education $^{\mathrm{c}}$} \\
\hline High school or less & $19 \cdot 6 \%$ & $20 \cdot 9 \%$ & $18 \cdot 3 \%$ & $14 \cdot 3 \%$ \\
\hline Some college & $44 \cdot 1 \%$ & $44 \cdot 2 \%$ & $58 \cdot 3 \%$ & $52 \cdot 4 \%$ \\
\hline College graduate or higher & $36 \cdot 3 \%$ & $34 \cdot 9 \%$ & $23 \cdot 3 \%$ & $33 \cdot 3 \%$ \\
\hline
\end{tabular}

BMI, body mass index.

a All cases: $F(1,160)=16 \cdot 91, p<0 \cdot 0001, \chi^{2}=0 \cdot 10$; analysed cases: $F(1,105)=0 \cdot 78, p=0 \cdot 38$.

b All cases: $F(1,159)=4 \cdot 38, p<0 \cdot 04, \chi^{2}=0 \cdot 027$; analysed cases: $F(1,104)=2 \cdot 76, p=0 \cdot 10$.

c All cases: $\chi^{2}(2)=3 \cdot 59, p=0 \cdot 17$; analysed cases: $\chi^{2}(2)=0 \cdot 64, p=0 \cdot 73$.

participant groups would be comparable to those in the Oxford risk factor study (Fairburn et al. 1998).

In all, the NEWHP recruited 162 women who met DSM-IV criteria for current BED. By requiring the identification of matched 'triplets', the size of the sample to be included in the analyses was determined by the group with the lowest number of members (the PC group). Therefore, the sample for the present study included 107 women with BED and 214 matched comparison women. Table 1 shows the demographic characteristics and the average onset age of the first clinically significant eating-disorder symptom (binge-eating, severe dieting, or purging), i.e. 'index age', of the complete NEWHP BED sample and the smaller BED sample that was included in the risk-factor analyses. The latter sample did not differ significantly from the complete BED sample in mean age or education. Reducing the BED sample to create matched triplets did, however, result in a sample of black women with BED that more closely resembled the white women on index age. While this design resulted in unyoked cases being excluded from the analysis, it allowed testing of hypotheses related to both general and specific effects using planned contrasts, as is described further in the data analysis section.

Women in the PC group carried the following diagnoses: mood disorder $(n=53,49.5 \%)$, anxiety disorder $(n=47,43.9 \%)$, substance disorder $(n=4,3 \cdot 7 \%)$, body dysmorphic disorder $(n=1,0.9 \%)$, adjustment disorder $(n=1,0.9 \%)$, and psychotic disorder not otherwise specified $(n=1,0.9 \%)$.

\section{Recruitment}

The recruitment and diagnostic assessment strategy has been described in previous articles (Pike et al. 2001; Striegel-Moore et al. 2002). The NEWHP recruited participants in the state of Connecticut, and in Boston, New York, and Los Angeles for a study of 'women's eating and mental health concerns'. Recruitment began in 1995 and ended in 1999. Eligibility criteria included being female, white or black, nonHispanic, born in the USA, and aged 18-40 years. Women who were pregnant or who had physical conditions known to influence eating habits or weight were excluded. Two recruitment strategies were used: one involved contacting approximately 10000 potential participants through a consumer information database; the other was an advertising campaign to recruit participants for a study of women's health. There was no selective ethnic bias in the results of the recruitment strategies $(51 \cdot 8 \%$ of the white women and $52.4 \%$ of the black women were recruited through the consumer database). Most healthy controls $(80.7 \%)$ were recruited from the consumer database, while most BED cases $(76.7 \%)$ were recruited through the advertising campaign. PC cases were recruited similarly from the consumer database $(53.7 \%)$ and the advertising campaign $(46 \cdot 3 \%)$.

Staff phoned all potential participants and determined eligibility for the study using a 15-min screening interview developed for the NEWHP (participation rate: 91\%). Information about race/ethnicity was obtained at the end of the call, using questions consistent with 
the USA census. Eligible women were invited to complete the diagnostic (First et al. 1996) and risk factor assessment interview (Fairburn et al. 1998). Participation rates for black and white women, respectively, were: BED $84.8 \%, 85 \cdot 2 \%$; HC $62.7 \%, 74.5 \%$; PC $76.6 \%, 73.9 \%$. Height and weight were measured at the end of this interview session.

Participants were ensured confidentiality of their responses and were paid for their time. For the phone screening, verbal informed consent was obtained. For the full interview, written informed consent was obtained. The study protocol was approved by the Institutional Review Boards of all participating institutions.

\section{Diagnostic assessment}

Diagnoses were determined using the Structured Clinical Interview for DSM-IV Axis I Disorders - Non-Patient Edition (SCID; First et al. 1996), and the Eating Disorder Examination (EDE; Fairburn \& Cooper, 1993), both standardized investigator-based interviews of well established reliability and validity (Segal et al. 1994; Rizvi et al. 2000). Index age was determined as part of the EDE assessment.

Staff participated in training workshops $(60$ and 40 hours for SCID and EDE, respectively) and training was continued until reaching $100 \%$ agreement between staff ratings and master trainer ratings of three consecutive SCID or EDE interviews. Staff participated in monthly supervision meetings and annual 2-day refresher workshops to avoid interviewer drift.

\section{Risk factor assessment}

Exposure to putative risk factors was assessed by interviewing participants using a modified version of the Oxford Risk Factor Interview (RFI; Fairburn et al. 1998). (The original RFI is available upon request from Dr Fairburn; a charge will be made to cover the cost of copying and postage.) The RFI measures biological, psychological, and social factors believed to place a person at risk for the development of an eating disorder. Questions about exposure to ethnic diversity were added and history of childhood obesity was ascertained by use of the body image silhouettes developed by Stunkard and colleagues (Sorsensen \& Stunkard, 1993). The RFI focuses on the period before onset of clinically significant eating symptoms or age
18 years (whichever came first), which ensures that exposure preceded the eating disorder and therefore could have contributed to its development. Individuals in the $\mathrm{HC}$ or PC group were assigned the index age of the BED case for which they served as the comparison subject; hence they were interviewed about the same age period as the subjects with BED, thereby matching for time of recall and for vulnerability to exposure.

The RFI was designed to minimize the problems associated with retrospective reporting. It uses clear behavioral definitions of key concepts and establishes a timeline for sequences of events (Bradburn, 2000). The RFI includes questions asked of everyone and, where appropriate, follow-up questions that are asked only if a key item is endorsed affirmatively. Items assess degree of exposure to a potential risk item using an ordinal scale, ranging from a low or null score, indicating no exposure, to a score of 3 or 4 indicating higher severity, longer duration, or higher frequency of exposure.

Participants also completed the Parental Bonding Instrument (PBI; Parker et al. 1979), a widely used and validated (Cox et al. 2000; Enns et al. 2002; Reti et al. 2002) self-report measure of participants' experience of both parents up to index age. From the PBI were extracted measures of parental affectionless control, overprotection, and low care (Parker et al. 1979). A wide range of putative risk factors was assessed representing a priori risk-domains (see Table 2) and risk-factor scales were constructed as described below.

\section{Data analysis}

\section{Data reduction}

To increase the reliability of the risk measurements, the first step in the data analysis involved six principal components factor analyses with varimax rotation of the risk-factor items. For these factor analyses, items were grouped into conceptually related broad risk-domains. Components with an eigenvalue exceeding 1 were retained. There were six domains of conceptually related items: subject's mental health; subject's physical health; family weight and eating concerns; quality of parenting; parental psychopathology; and other environmental experiences. As shown in Table 2, 22 components 
Table 2. Results of factor analyses of risk-factor variables by conceptual domain ${ }^{\mathrm{a}, \mathrm{b}}$

\begin{tabular}{|c|c|c|}
\hline Conceptual domain & Components extracted & RFI items comprising each component \\
\hline Subject's mental health & $\begin{array}{l}\text { 1. Conduct problems } \\
\text { 2. Negative affectivity } \\
\text { 3. Substance abuse } \\
\text { 4. Perfectionism }\end{array}$ & $\begin{array}{l}\text { Conduct problems } \\
\text { Truancy } \\
\text { Negative self-esteem } \\
\text { Shyness } \\
\text { Absence of friends } \\
\text { School anxiety } \\
\text { Major depression } \\
\text { Drug abuse } \\
\text { Alcohol abuse } \\
\text { Perfectionism } \\
\text { Extreme compliance }\end{array}$ \\
\hline Subject's physical health ${ }^{\mathrm{c}}$ & $\begin{array}{l}\text { 1. Pregnancy history } \\
\text { 2. Severe childhood obesity }\end{array}$ & $\begin{array}{l}\text { Pregnancy } \\
\text { Abortion } \\
\text { No. of children } \\
\text { Obesity } \\
\text { Advised to lose weight } \\
\text { Diet prescribed }\end{array}$ \\
\hline $\begin{array}{l}\text { Other environmental } \\
\text { experiences }\end{array}$ & $\begin{array}{l}\text { 1. Exposure to ethnic diversity } \\
\text { 2. Disruptions and deprivation }\end{array}$ & $\begin{array}{l}\text { Neighborhood diversity } \\
\text { School diversity } \\
\text { Diverse friends } \\
\text { Food deprivation } \\
\text { Frequent moves } \\
\text { Change of caregiver }\end{array}$ \\
\hline $\begin{array}{l}\text { Family weight and eating } \\
\text { concerns }^{\mathrm{d}}\end{array}$ & $\begin{array}{l}\text { 1. Family dieting } \\
\text { 2. Maternal overweight } \\
\text { 3. Family history of anorexia nervosa } \\
\text { 4. Paternal overweight } \\
\text { 5. Family history of bulimia nervosa } \\
\text { 6. Family overeating }\end{array}$ & $\begin{array}{l}\text { Dieting: } n \text { family members } \\
\text { Dieting: mother } \\
\text { Dieting: father } \\
\text { Dieting: sister } \\
\text { Mother's highest weight } \\
\text { Mother's lowest weight } \\
\text { Parental anorexia nervosa } \\
\text { Low weight: } n \text { family members } \\
\text { Anorexia nervosa: } n \text { family members } \\
\text { Father's highest weight } \\
\text { Father's lowest weight } \\
\text { Parental bulimia nervosa } \\
\text { Weight concern: } n \text { family members } \\
\text { Bulimia nervosa: } n \text { family members } \\
\text { Objective overeating: } n \text { family members } \\
\text { Binge-eating disorder: } n \text { family members }\end{array}$ \\
\hline Quality of parenting & $\begin{array}{l}\text { 1. Maternal problem parenting } \\
\text { 2. Family discord } \\
\text { 3. Paternal problem parenting } \\
\text { 4. Separations from parent } \\
\text { 5. Parental absence or death } \\
\text { 6. High parental demands }\end{array}$ & $\begin{array}{l}\text { Maternal low care } \\
\text { Maternal overprotection } \\
\text { Maternal affectionless control } \\
\text { Low contact with parent } \\
\text { Parental arguments } \\
\text { Parental low affection } \\
\text { Family tension at mealtimes } \\
\text { Paternal low care } \\
\text { Paternal overprotection } \\
\text { Paternal affectionless control } \\
\text { Separation from parent } \\
\text { Boarding school } \\
\text { Parental absence from family } \\
\text { Parental death } \\
\text { Parental high expectations } \\
\text { Parental criticism } \\
\text { Parental ill health }\end{array}$ \\
\hline Parental psychopathology & 1. Parental mood and substance disorder & $\begin{array}{l}\text { Parental major depression } \\
\text { Parental alcohol problem } \\
\text { Parental drug problem }\end{array}$ \\
\hline
\end{tabular}

RFI, Oxford Risk Factor Interview.

a The risk-factor variables within each conceptual domain were analyzed in a separate principal components factor analysis with varimax rotation. Components with an eigenvalue $>1$ were retained.

b All variables reflect exposure before the participant's index age.

c Item excluded because it correlated $<0.30$ with any factor: Physical illness.

d Item excluded because it correlated $<0 \cdot 30$ with any factor: Dieting, brother. 
were identified during the data reduction stage. Composite variables ('risk-factor scales') representing the components were created by summing the standardized scores for each item with a factor loading above 0.30 on a particular component. All 22 scales were retained for analysis because there was little overlap among them. The highest correlation between any two was 0.36 ('Maternal Overweight' and 'Family Overeating').

\section{Site differences}

Because our samples were recruited from three distinct geographic sites, we examined site effects using multivariate analysis of variance (ANOVA). No significant site or site-byethnicity effects were found for any of the risk factors (site: $F_{(26,72)}=0 \cdot 89, p=0 \cdot 62$; site-by-race: $\left.F_{(26,76)}=0 \cdot 76, p=0 \cdot 76\right)$.

\section{Hypothesis-testing}

The three groups (BED, PC, and $\mathrm{HC}$ ) were compared using separate repeated measures analyses of variance for each risk-factor scale. Diagnostic group (BED, PC, and HC) represented the within-subject variable, and ethnicity represented the between-subject variable. The repeated-measures design was used because each comparison subject was 'yoked' to a specific BED case, based on ethnicity, education, age, and index age. If the overall $F$ ratio for the risk-factor scale was significant, the results for two contrasts were examined. The first contrast compared BED cases with PC cases; a significant group difference suggested that risk was specific to BED rather than reflecting increased risk for a mental disorder more generally. The second contrast combined the BED and PC cases into a single group representing cases with an Axis-I disorder and compared these with the HC group; a significant group difference here suggested non-specific increased risk for a mental disorder. Given the number of comparisons examined, the significance level was set at $p<0 \cdot 01$.

\section{RESULTS}

\section{Overview}

Table 3 summarizes the results of the comparisons of the BED women with the matched PC and $\mathrm{HC}$ groups, by ethnicity. No significant ethnicity $\times$ diagnostic group effects were found, suggesting that the associations between putative risk factors and diagnostic group status did not vary by ethnicity. For several risk-factor scales, no significant main effects were found, indicating that the variables in question were not associated significantly with BED or PC status: Substance Abuse or Conduct Problems (subject's mental health); Disruptions and Deprivation (other environmental experiences); Family Dieting, Maternal Overweight, Paternal Overweight, and Family History of Bulimia Nervosa (family weight and eating concerns); and $\mathrm{Pa}$ ternal Problem Parenting (quality of parenting). For a few of the risk-factor scales, significant ethnic group differences were found. Compared with white women, black women scored significantly higher on Pregnancy History (subject's physical health), Exposure to Ethnic Diversity (other environmental experiences), and Separations from Parents and Parental Absences or Death (quality of parenting). White women scored higher than black women on Family Overeating (family weight and eating concerns).

Where a significant diagnostic group difference was found, effect sizes (and $p$ values) for the planned contrasts are shown in Table 4. Significant findings are described first for the planned contrasts comparing women with BED and the matched PC group, followed by a description of results of the contrasts comparing the two psychiatric groups (BED and PC) with the matched HC group.

\section{Specific risk factors for BED}

Women with BED scored significantly higher than PC women on the Severe Childhood Obesity scale (subject's physical health) and on the Family Overeating scale (family eating and weight concerns), with effect sizes suggesting moderate to large group differences (Cohen, 1988). In the risk-domain of inadequate parenting, moderate effect sizes were observed, whereby women with BED obtained significantly higher scores compared with the PC group on the Family Discord scale and the High Parental Demands scale.

\section{General risk factors for psychiatric disorder}

Planned contrasts comparing the two groups of women with a current psychiatric diagnosis 
Table 3. Repeated measures results for risk factors by race, with group means ${ }^{\mathrm{a}}$ and standard deviations

\begin{tabular}{|c|c|c|c|c|c|c|c|c|c|}
\hline \multirow[b]{2}{*}{$\begin{array}{l}\text { Scale (no. of variables } \\
\text { included in scale) }\end{array}$} & \multicolumn{2}{|c|}{ BED } & \multicolumn{2}{|c|}{$\mathrm{PC}$} & \multicolumn{2}{|c|}{$\mathrm{HC}$} & \multirow{2}{*}{$\begin{array}{c}\text { Diagnosis } \\
\text { (D) } \\
F(p)\end{array}$} & \multirow{2}{*}{$\begin{array}{c}\text { Ethnicity } \\
(\mathrm{E})^{\mathrm{d}} \\
F(p)\end{array}$} & \multirow[b]{2}{*}{$\begin{array}{l}\mathrm{D} \times \mathrm{E}^{\mathrm{e}} \\
F(p)\end{array}$} \\
\hline & $\begin{array}{l}\text { White } \\
\text { M (s.D.) }\end{array}$ & $\begin{array}{c}\text { Black } \\
\text { M (s.D.) }\end{array}$ & $\begin{array}{l}\text { White } \\
\text { M (s.D.) }\end{array}$ & $\begin{array}{c}\text { Black } \\
\text { M (s.D.) }\end{array}$ & $\begin{array}{l}\text { White } \\
\text { M (s.D.) }\end{array}$ & $\begin{array}{c}\text { Black } \\
\text { M (s.D.) }\end{array}$ & & & \\
\hline \multicolumn{10}{|c|}{ Conceptual domain: Subject's mental health } \\
\hline Conduct problems (2) & $\begin{array}{c}0 \cdot 34 \\
(2 \cdot 27)\end{array}$ & $\begin{array}{c}0 \cdot 53 \\
(2 \cdot 76)\end{array}$ & $\begin{array}{r}-0 \cdot 04 \\
(1 \cdot 77)\end{array}$ & $\begin{array}{c}0 \cdot 12 \\
(2 \cdot 08)\end{array}$ & $\begin{array}{r}-0 \cdot 19 \\
(1 \cdot 46)\end{array}$ & $\begin{array}{c}-0 \cdot 31 \\
(0 \cdot 83)\end{array}$ & $\begin{array}{l}2 \cdot 11 \\
(0 \cdot 12)\end{array}$ & $\begin{array}{c}0 \cdot 09 \\
(0 \cdot 76)\end{array}$ & $\begin{array}{c}0 \cdot 13 \\
(0 \cdot 88)\end{array}$ \\
\hline Negative affectivity (5) & $\begin{array}{l}1.90 \\
(3 \cdot 68)\end{array}$ & $\begin{array}{c}1 \cdot 81 \\
(3 \cdot 51)\end{array}$ & $\begin{array}{c}1 \cdot 09 \\
(3 \cdot 64)\end{array}$ & $\begin{array}{c}0 \cdot 66 \\
(2 \cdot 86)\end{array}$ & $\begin{array}{r}-0.89 \\
(1 \cdot 40)\end{array}$ & $\begin{array}{r}-0.88 \\
(1.54)\end{array}$ & $\begin{array}{l}14 \cdot 00 \\
(0 \cdot 0001)\end{array}$ & $\begin{array}{c}0 \cdot 16 \\
(0 \cdot 69)\end{array}$ & $\begin{array}{c}0 \cdot 10 \\
(0 \cdot 91)\end{array}$ \\
\hline Substance abuse (2) & $\begin{array}{c}0 \cdot 29 \\
(2 \cdot 20)\end{array}$ & $\begin{array}{r}-0 \cdot 39 \\
(0 \cdot 04)\end{array}$ & $\begin{array}{c}0.05 \\
(1 \cdot 41)\end{array}$ & $\begin{array}{c}0 \cdot 15 \\
(2 \cdot 47)\end{array}$ & $\begin{array}{c}-0.05 \\
(1.52)\end{array}$ & $\begin{array}{l}0 \cdot 15 \\
(2 \cdot 47)\end{array}$ & $\begin{array}{c}0 \cdot 15 \\
(0 \cdot 86)\end{array}$ & $\begin{array}{l}0 \cdot 20 \\
(0 \cdot 65)\end{array}$ & $\begin{array}{l}1 \cdot 44 \\
(0 \cdot 24)\end{array}$ \\
\hline Perfectionism (2) & $\begin{array}{c}0 \cdot 44 \\
(1 \cdot 71)\end{array}$ & $\begin{array}{c}1 \cdot 12 \\
(2 \cdot 34)\end{array}$ & $\begin{array}{l}0 \cdot 57 \\
(1 \cdot 95)\end{array}$ & $\begin{array}{c}0 \cdot 02 \\
(1 \cdot 78)\end{array}$ & $\begin{array}{c}-0 \cdot 04 \\
(1 \cdot 38)\end{array}$ & $\begin{array}{r}-0.52 \\
(0.91)\end{array}$ & $\begin{array}{l}7 \cdot 46 \\
(0 \cdot 001)\end{array}$ & $\begin{array}{l}0 \cdot 19 \\
(0 \cdot 66)\end{array}$ & $\begin{array}{l}3 \cdot 15 \\
(0 \cdot 05)\end{array}$ \\
\hline \multicolumn{10}{|c|}{ Conceptual domain: Subject's physical health } \\
\hline Pregnancy history (3) & $\begin{array}{r}-0 \cdot 10 \\
(2 \cdot 58)\end{array}$ & $\begin{array}{l}0 \cdot 27 \\
(2 \cdot 67)\end{array}$ & $\begin{array}{r}-0 \cdot 63 \\
(1 \cdot 24)\end{array}$ & $\begin{array}{c}0 \cdot 89 \\
(4 \cdot 37)\end{array}$ & $\begin{array}{c}-0.52 \\
(1.66)\end{array}$ & $\begin{array}{c}1 \cdot 07 \\
(4 \cdot 14)\end{array}$ & $\begin{array}{l}0 \cdot 15 \\
(0 \cdot 87)\end{array}$ & $\begin{array}{l}8 \cdot 61 \\
(0 \cdot 004)\end{array}$ & $\begin{array}{l}1 \cdot 71 \\
(0 \cdot 18)\end{array}$ \\
\hline Severe childhood obesity (3) & $\begin{array}{c}1 \cdot 25 \\
(30 \cdot 79)\end{array}$ & $\begin{array}{c}2 \cdot 17 \\
(40 \cdot 08)\end{array}$ & $\begin{array}{c}-0.44 \\
(1 \cdot 21)\end{array}$ & $\begin{array}{l}-0.20 \\
(1.33)\end{array}$ & $\begin{array}{r}-0.52 \\
(0.83)\end{array}$ & $\begin{array}{c}-0 \cdot 12 \\
(1 \cdot 29)\end{array}$ & $\begin{array}{l}15 \cdot 76 \\
(0 \cdot 0001)\end{array}$ & $\begin{array}{l}2 \cdot 50 \\
(0 \cdot 12)\end{array}$ & $\begin{array}{c}0 \cdot 37 \\
(0 \cdot 69)\end{array}$ \\
\hline \multicolumn{10}{|c|}{ Conceptual domain: Other environmental experiences } \\
\hline $\begin{array}{l}\text { Exposure to ethnic } \\
\text { diversity (3) }\end{array}$ & $\begin{array}{c}-0 \cdot 24 \\
(2 \cdot 21)\end{array}$ & $\begin{array}{l}1.48 \\
(2 \cdot 99)\end{array}$ & $\begin{array}{r}-0 \cdot 39 \\
(2 \cdot 42)\end{array}$ & $\begin{array}{c}0 \cdot 81 \\
(2 \cdot 63)\end{array}$ & $\begin{array}{c}-0 \cdot 31 \\
(2 \cdot 38)\end{array}$ & $\begin{array}{l}2 \cdot 01 \\
(2 \cdot 70)\end{array}$ & $\begin{array}{l}1 \cdot 30 \\
(0 \cdot 27)\end{array}$ & $\begin{array}{l}22 \cdot 34 \\
(0 \cdot 0001)\end{array}$ & $\begin{array}{c}0 \cdot 97 \\
(0 \cdot 38)\end{array}$ \\
\hline $\begin{array}{r}\text { Disruptions and } \\
\text { deprivation (3) }\end{array}$ & $\begin{array}{c}0 \cdot 51 \\
(2 \cdot 43)\end{array}$ & $\begin{array}{c}0 \cdot 36 \\
(1.93)\end{array}$ & $\begin{array}{c}-0.42 \\
(1.43)\end{array}$ & $\begin{array}{l}1 \cdot 35 \\
(2 \cdot 94)\end{array}$ & $\begin{array}{c}-0 \cdot 17 \\
(2 \cdot 18)\end{array}$ & $\begin{array}{r}-0 \cdot 04 \\
(1 \cdot 49)\end{array}$ & $\begin{array}{l}1 \cdot 67 \\
(0 \cdot 19)\end{array}$ & $\begin{array}{c}3 \cdot 64 \\
(0 \cdot 06)\end{array}$ & $\begin{array}{l}4 \cdot 35 \\
(0 \cdot 014)\end{array}$ \\
\hline \multicolumn{10}{|c|}{ Conceptual domain: Family weight and eating concerns } \\
\hline Family dieting (4) & $\begin{array}{c}1 \cdot 96 \\
(4 \cdot 06)\end{array}$ & $\begin{array}{c}0 \cdot 44 \\
(3 \cdot 32)\end{array}$ & $\begin{array}{c}0 \cdot 54 \\
(3 \cdot 32)\end{array}$ & $\begin{array}{c}0 \cdot 03 \\
(2 \cdot 39)\end{array}$ & $\begin{array}{c}0 \cdot 13 \\
(3 \cdot 22)\end{array}$ & $\begin{array}{c}-1 \cdot 05 \\
(2 \cdot 03)\end{array}$ & $\begin{array}{l}4 \cdot 46 \\
(0 \cdot 013)\end{array}$ & $\begin{array}{c}4 \cdot 40 \\
(0 \cdot 04)\end{array}$ & $\begin{array}{c}0 \cdot 37 \\
(0 \cdot 69)\end{array}$ \\
\hline Maternal overweight (2) & $\begin{array}{l}0 \cdot 65 \\
(1 \cdot 60)\end{array}$ & $\begin{array}{c}0 \cdot 82 \\
(2 \cdot 03)\end{array}$ & $\begin{array}{c}0 \cdot 62 \\
(1 \cdot 36)\end{array}$ & $\begin{array}{c}0 \cdot 90 \\
(0 \cdot 90)\end{array}$ & $\begin{array}{c}0 \cdot 47 \\
(1 \cdot 17)\end{array}$ & $\begin{array}{r}-0.08 \\
(1.58)\end{array}$ & $\begin{array}{l}3 \cdot 19 \\
(0 \cdot 04)\end{array}$ & $\begin{array}{c}0 \cdot 03 \\
(0 \cdot 87)\end{array}$ & $\begin{array}{l}1 \cdot 65 \\
(0 \cdot 19)\end{array}$ \\
\hline $\begin{array}{l}\text { Family history of } \\
\text { anorexia nervosa (3) }\end{array}$ & $\begin{array}{c}0 \cdot 97 \\
(4 \cdot 47)\end{array}$ & $\begin{array}{c}-0 \cdot 44 \\
(0 \cdot 05)\end{array}$ & $\begin{array}{c}0.66 \\
(3 \cdot 61)\end{array}$ & $\begin{array}{l}-0.43 \\
(0.0001)\end{array}$ & $\begin{array}{l}-0.43 \\
(0.0001)\end{array}$ & $\begin{array}{l}-0.43 \\
(0.0001)\end{array}$ & $\begin{array}{c}0 \cdot 97 \\
(0 \cdot 38)\end{array}$ & $\begin{array}{c}4 \cdot 20 \\
(0 \cdot 04)\end{array}$ & $\begin{array}{c}0 \cdot 99 \\
(0 \cdot 37)\end{array}$ \\
\hline Paternal overweight (2) & $\begin{array}{c}0 \cdot 55 \\
(1 \cdot 60)\end{array}$ & $\begin{array}{l}0 \cdot 10 \\
(1 \cdot 83)\end{array}$ & $\begin{array}{c}0 \cdot 54 \\
(1 \cdot 58)\end{array}$ & $\begin{array}{l}-0 \cdot 10 \\
(1 \cdot 71)\end{array}$ & $\begin{array}{c}0 \cdot 50 \\
(1 \cdot 20)\end{array}$ & $\begin{array}{l}0.40 \\
(1.91)\end{array}$ & $\begin{array}{c}0 \cdot 38 \\
(0 \cdot 68)\end{array}$ & $\begin{array}{c}3 \cdot 07 \\
(0 \cdot 08)\end{array}$ & $\begin{array}{c}0 \cdot 55 \\
(0 \cdot 58)\end{array}$ \\
\hline $\begin{array}{l}\text { Family history of bulimia } \\
\text { nervosa (3) }\end{array}$ & $\begin{array}{c}0 \cdot 56 \\
(3 \cdot 22)\end{array}$ & $\begin{array}{r}-0 \cdot 35 \\
(0 \cdot 80)\end{array}$ & $\begin{array}{c}0 \cdot 58 \\
(3 \cdot 75)\end{array}$ & $\begin{array}{c}0 \cdot 18 \\
(1 \cdot 47)\end{array}$ & $\begin{array}{r}-0.30 \\
(1.03)\end{array}$ & $\begin{array}{r}-0 \cdot 34 \\
(0 \cdot 80)\end{array}$ & $\begin{array}{l}1 \cdot 16 \\
(0 \cdot 33)\end{array}$ & $\begin{array}{c}1 \cdot 51 \\
(0 \cdot 22)\end{array}$ & $\begin{array}{c}0 \cdot 44 \\
(0 \cdot 64)\end{array}$ \\
\hline Family overeating (2) & $\begin{array}{l}1 \cdot 66 \\
(2 \cdot 73)\end{array}$ & $\begin{array}{c}0 \cdot 40 \\
(2 \cdot 24)\end{array}$ & $\begin{array}{c}-0 \cdot 22 \\
(1 \cdot 38)\end{array}$ & $\begin{array}{r}-0 \cdot 64 \\
(0.38)\end{array}$ & $\begin{array}{c}-0 \cdot 44 \\
(1 \cdot 21)\end{array}$ & $\begin{array}{r}-0 \cdot 64 \\
(0.38)\end{array}$ & $\begin{array}{l}14 \cdot 95 \\
(0 \cdot 0001)\end{array}$ & $\begin{array}{l}7 \cdot 07 \\
(0 \cdot 009)\end{array}$ & $\begin{array}{l}1 \cdot 53 \\
(0 \cdot 22)\end{array}$ \\
\hline \multicolumn{10}{|c|}{ Conceptual domain: Quality of parenting } \\
\hline Maternal problem parenting (3) & $\begin{array}{l}1 \cdot 08 \\
(2 \cdot 31)\end{array}$ & $\begin{array}{l}1 \cdot 65 \\
(2 \cdot 29)\end{array}$ & $\begin{array}{c}0 \cdot 58 \\
(2 \cdot 44)\end{array}$ & $\begin{array}{c}0 \cdot 84 \\
(2 \cdot 46)\end{array}$ & $\begin{array}{c}-0 \cdot 26 \\
(2 \cdot 48)\end{array}$ & $\begin{array}{c}0 \cdot 26 \\
(2 \cdot 77)\end{array}$ & $\begin{array}{l}5 \cdot 55 \\
(0 \cdot 004)\end{array}$ & $\begin{array}{c}1 \cdot 60 \\
(0 \cdot 21)\end{array}$ & $\begin{array}{c}0 \cdot 09 \\
(0 \cdot 92)\end{array}$ \\
\hline Family discord (4) & $\begin{array}{l}1.93 \\
(2 \cdot 95)\end{array}$ & $\begin{array}{l}1 \cdot 29 \\
(2 \cdot 81)\end{array}$ & $\begin{array}{l}0 \cdot 60 \\
(2 \cdot 48)\end{array}$ & $\begin{array}{c}0 \cdot 27 \\
(1 \cdot 96)\end{array}$ & $\begin{array}{c}-0.21 \\
(2 \cdot 60)\end{array}$ & $\begin{array}{r}-1.20 \\
(1.41)\end{array}$ & $\begin{array}{l}13 \cdot 52 \\
(0 \cdot 0001)\end{array}$ & $\begin{array}{l}3 \cdot 25 \\
(0 \cdot 07)\end{array}$ & $\begin{array}{c}0 \cdot 26 \\
(0 \cdot 77)\end{array}$ \\
\hline Paternal problem parenting (3) & $\begin{array}{l}1 \cdot 20 \\
(2 \cdot 36)\end{array}$ & $\begin{array}{c}0 \cdot 97 \\
(2 \cdot 44)\end{array}$ & $\begin{array}{c}0 \cdot 77 \\
(2 \cdot 41)\end{array}$ & $\begin{array}{c}0 \cdot 54 \\
(2 \cdot 72)\end{array}$ & $\begin{array}{r}-0 \cdot 40 \\
(2 \cdot 32)\end{array}$ & $\begin{array}{c}0 \cdot 34 \\
(2 \cdot 40)\end{array}$ & $\begin{array}{l}4 \cdot 24 \\
(0 \cdot 016)\end{array}$ & $\begin{array}{c}0 \cdot 06 \\
(0 \cdot 81)\end{array}$ & $\begin{array}{l}1 \cdot 03 \\
(0 \cdot 36)\end{array}$ \\
\hline Separations from parent (2) & $\begin{array}{c}0 \cdot 39 \\
(1 \cdot 87)\end{array}$ & $\begin{array}{l}1 \cdot 14 \\
(2 \cdot 45)\end{array}$ & $\begin{array}{r}0 \cdot 005 \\
(1 \cdot 44)\end{array}$ & $\begin{array}{l}1 \cdot 41 \\
(2 \cdot 87)\end{array}$ & $\begin{array}{r}-0 \cdot 18 \\
(0 \cdot 87)\end{array}$ & $\begin{array}{c}0 \cdot 07 \\
(1 \cdot 34)\end{array}$ & $\begin{array}{l}4 \cdot 90 \\
(0 \cdot 008)\end{array}$ & $\begin{array}{l}13 \cdot 13 \\
(0 \cdot 0001)\end{array}$ & $\begin{array}{l}1.97 \\
(0 \cdot 14)\end{array}$ \\
\hline Parental absence or death (2) & $\begin{array}{c}0 \cdot 27 \\
(1 \cdot 29)\end{array}$ & $\begin{array}{c}0 \cdot 75 \\
(1 \cdot 59)\end{array}$ & $\begin{array}{c}0 \cdot 01 \\
(1 \cdot 03)\end{array}$ & $\begin{array}{c}1 \cdot 16 \\
(2 \cdot 48)\end{array}$ & $\begin{array}{c}0 \cdot 11 \\
(1 \cdot 19)\end{array}$ & $\begin{array}{c}0 \cdot 33 \\
(1 \cdot 39)\end{array}$ & $\begin{array}{l}1 \cdot 45 \\
(0 \cdot 24)\end{array}$ & $\begin{array}{l}9 \cdot 20 \\
(0 \cdot 003)\end{array}$ & $\begin{array}{c}2 \cdot 52 \\
(0 \cdot 08)\end{array}$ \\
\hline High parental demands ( 3 ) & $\begin{array}{l}1 \cdot 04 \\
(2 \cdot 08)\end{array}$ & $\begin{array}{l}1 \cdot 27 \\
(2 \cdot 80)\end{array}$ & $\begin{array}{c}0 \cdot 33 \\
(2 \cdot 33)\end{array}$ & $\begin{array}{c}-0.52 \\
(1.20)\end{array}$ & $\begin{array}{c}-0.41 \\
(1.79)\end{array}$ & $\begin{array}{r}-0.38 \\
(1.52)\end{array}$ & $\begin{array}{l}10 \cdot 93 \\
(0 \cdot 0001)\end{array}$ & $\begin{array}{c}0 \cdot 46 \\
(0 \cdot 50)\end{array}$ & $\begin{array}{l}1 \cdot 35 \\
(0 \cdot 26)\end{array}$ \\
\hline \multicolumn{10}{|c|}{ Conceptual domain: Parental psychopathology } \\
\hline $\begin{array}{l}\text { Parental mood and } \\
\text { substance disorder (3) }\end{array}$ & $\begin{array}{l}1 \cdot 23 \\
(2 \cdot 76)\end{array}$ & $\begin{array}{c}0.94 \\
(2 \cdot 81)\end{array}$ & $\begin{array}{c}0 \cdot 53 \\
(2 \cdot 19)\end{array}$ & $\begin{array}{c}0 \cdot 24 \\
(1 \cdot 93)\end{array}$ & $\begin{array}{r}-0.48 \\
(1.52)\end{array}$ & $\begin{array}{c}-0 \cdot 84 \\
(0 \cdot 96)\end{array}$ & $\begin{array}{l}11 \cdot 20 \\
(0 \cdot 0001)\end{array}$ & $\begin{array}{c}0 \cdot 99 \\
(0 \cdot 32)\end{array}$ & $\begin{array}{c}0 \cdot 01 \\
(0 \cdot 99)\end{array}$ \\
\hline
\end{tabular}

BED, binge-eating disorder group; $\mathrm{PC}$, psychiatric comparison group; $\mathrm{HC}$, healthy comparison group

${ }^{a}$ Group means represent the average sum of the standardized scores for the variables included in the factor. They can be interpreted as deviations from the mean.

b All variables reflect exposure before the participant's index age.

${ }^{c}$ df $2,210 .{ }^{d}$ df $1,105 .{ }^{e}$ df $2,210$.

(BED or PC) with the matched $\mathrm{HC}$ group identified five general, additional risk factors. Compared with the HC group, the two groups with a current psychiatric disorder scored significantly higher on the Negative Affectivity scale (subjects' mental health), the Parental 
Table 4. Effect sizes (Cohen's d) and significance levels for significant contrast effects ${ }^{\mathrm{a}, \mathrm{b}}$

\begin{tabular}{|c|c|c|}
\hline & \multicolumn{2}{|c|}{ Diagnostic contrast } \\
\hline & $\begin{array}{l}\text { BED versus } \mathrm{PC} \\
\text { Cohen's } d(p)\end{array}$ & $\begin{array}{c}\mathrm{BED}+\mathrm{PC} \\
\text { versus } \mathrm{HC} \\
\text { Cohen's } d(p)\end{array}$ \\
\hline \multicolumn{3}{|l|}{ Specific effects } \\
\hline Severe childhood obesity & $0 \cdot 64(0 \cdot 0001)$ & $0 \cdot 50(0.0001)$ \\
\hline Family overeating & $0.82(0.0001)$ & $0.65(0.0001)$ \\
\hline Family discord & $0.48(0.01)$ & $0.62(0.0001)$ \\
\hline High parental demands & $0.42(0.0001)$ & $0.52(0.003)$ \\
\hline \multicolumn{3}{|l|}{ General effects } \\
\hline Negative affectivity & - & $0.85(0.0001)$ \\
\hline $\begin{array}{l}\text { Parental mood and } \\
\text { substance disorder }\end{array}$ & - & $0.69(0.0001)$ \\
\hline Perfectionism & - & $0 \cdot 40(0.0001)$ \\
\hline Separations from parent & - & $0 \cdot 35(0.0001)$ \\
\hline Maternal problem parenting & - & $0.31(0.007)$ \\
\hline
\end{tabular}

BED, binge-eating disorder group; $\mathrm{PC}$, psychiatric comparison group; $\mathrm{HC}$, healthy comparison group.

a All variables reflect exposure before the participant's index age.

b Cohen's $d=$ mean $1-$ mean $2 /$ s.D. pooled; small effect, $0 \cdot 20$; medium effect, $0 \cdot 50$; large effect, $0 \cdot 80$.

Mood and Substance Disorder scale (parental psychopathology), the Perfectionism scale (subjects' mental health), the Separations from Parents scale (quality of parenting), and the Maternal Problem Parenting scale (quality of parenting).

\section{DISCUSSION}

This is the first comprehensive study of risk factors for BED conducted in the USA. Our study replicated and extended a previous casecontrol study of risk factors for BED conducted in Oxford, UK (Fairburn et al. 1998). The casecontrol design was selected because it is the design of choice when little is known about etiology of the disorder under study, and the disorder is relatively uncommon and likely involves a long time period between exposure to risk and onset. These features are characteristic of $\mathrm{BED}$, rendering prospective studies very expensive (Striegel-Moore \& Cachelin, 2001). Data gleaned from a case-control study can provide useful information to narrow the list of possible risk factors and generate hypotheses to be tested in subsequent prospective studies of high risk groups. By definition, risk factors precede onset of the disorder (Kraemer et al. 1997); given the retrospective reporting of exposure to risk, results from our study need to be interpreted cautiously.

Several aspects of our methodology are of note. All participants were recruited from the community, thereby avoiding the sampling biases that may arise from focusing on patients in treatment (Fairburn et al. 1996; Wilfley et al. 2001). For example, treatment studies have a disproportionately low representation of minority patients with BED (Wilfley et al. 2001), and we successfully recruited black women with BED for the present study. Consistent with the Oxford study, we assessed a large number of putative risk factors that have been hypothesized to be associated with eating disorders (StriegelMoore et al. 1986) and added a measure of exposure to ethnic diversity, a risk factor that has been hypothesized to contribute to risk for eating disorders in black women (Smolak \& Striegel-Moore, 2001). We included a psychiatric comparison group to examine whether certain risk factors are especially common among women with BED rather than being associated with psychiatric status in general. Finally, all participants were assessed with state-of-the-art diagnostic interviews by carefully trained staff.

Our findings based on comparisons of women with BED and their matched psychiatric comparison group suggest several specific risk factors for BED in black and white women. Consistent with the Oxford study, women with BED scored significantly higher than PC women on the measure of childhood obesity, which incorporated the individual items of childhood obesity and social pressure about obesity used in the Oxford study. The Oxford study further found elevated rates of familial eating disorders among women with BED compared with psychiatric comparison women. In the present study, we found that family overeating or bingeeating, but not familial anorexia nervosa, bulimia nervosa, or family dieting, was associated significantly with BED. This inconsistency requires further exploration. Our results suggest that family binge-eating, but not dieting or other inappropriate compensatory behaviors that characterize anorexia nervosa or bulimia nervosa, is associated with risk for BED. This is consistent with genetic-epidemiology studies that have found high rates of familial aggregation of specific forms of disordered eating (Sullivan et al. 1998; Bulik et al. 2000). 
Prospective studies will be needed to disentangle the temporal relationship between severe childhood obesity and family overeating. For example, one might hypothesize that overeating in the family contributes to an increased risk for childhood obesity.

Compared with women without BED, women with BED reported significantly greater levels of Family Discord, a scale reflecting family tension at mealtimes, frequent arguments between parents, low parental affection, and limited contact with parents. Moreover, women with BED scored significantly higher on the High Parental Demands scale, measuring parental high expectations, frequent criticism of the respondent and parental ill health. These findings are consistent with the Oxford study where low parental contact and high parental expectations were found to be associated specifically with BED. This constellation of specific risk factors for BED is consistent with the 'interpersonal vulnerability model of binge-eating' which describes binge-eating as the coping response to negative affective states that, in turn, are the consequences of unsupportive yet demanding parenting and stressful experiences such as high levels of family conflict (Wilfley et al. 1997). The model further suggests that the particular symptom choice, binge-eating, is the result of social learning processes. Our design does not permit us to test mediational processes; prospective or experimental designs are needed to examine the mechanisms that underlie the significant associations found between personal and familial risk factors and BED.

Several additional general risk factors appear to further contribute to vulnerability for BED, including negative affectivity and perfectionism, and parental characteristics such as high rates of psychopathology, frequent separations of the child from the parent, and a parenting style marked by low affection but high levels of control. These variables are commonly identified as risk factors for psychiatric disorders in general (Kendler et al. 1995; Kessler et al. 1997). It is of note that perfectionism has been shown to be associated specifically with risk for anorexia nervosa (Fairburn et al. 1999; Halmi et al. 2000; Lilenfeld et al. 2000) and bulimia nervosa (Fairburn et al. 1997; Lilenfeld et al. 2000) but not BED (Fairburn et al. 1998). Hence, perfectionism may be among the variables that explain differential risk for BED versus anorexia or bulimia nervosa.

Black women have been under-studied in eating disorders and were specifically recruited for the present study to examine whether ethnicity moderated risk for developing BED. In our complete BED sample we found that the average age of onset of the first clinically significant behavior symptom was earlier in the white women compared with the black women. A similar result was found in another study of a large community-based cohort of black and white women (Striegel-Moore et al. 2003). It is of note that we did not find evidence of an ethnicity-specific effect of any of the risk factors assessed in this study. There were a few ethnic differences on the risk-factor scales and the effect sizes indicated that these differences were small to moderate. Specifically, black women scored higher than white women on Exposure to Ethnic Diversity, a finding that is not surprising given that black women represent a numerical minority in the population. They therefore are more likely to encounter non-black women than white women are to encounter black women in various social contexts. Our findings did not support the hypothesis that black women who frequently interacted with white individuals are more likely to meet criteria for BED than black women who reported low exposure to white individuals. This negative finding may reflect the lack of social norms (e.g. emphasis on thinness) contributing to risk for BED. Hence, the amount of exposure to white social norms may be irrelevant for an understanding of risk for BED.

Black women were significantly less likely to endorse questions about overeating in the family than white women. Unlike the questions about the subject's own overeating, where the interviewer ascertained amounts of food consumed during the overeating episode, questions about family overeating relied on the subject's assessment of what constituted overeating. Whether the lower scores observed among black women on this variable reflect ethnic differences in definitions of 'overeating' requires further investigation (Dohm \& Striegel-Moore, 2002). The ethnic group difference in ratings of Family Overeating notwithstanding, this variable was found to be associated specifically with BED in both black and white women. 
Limitations that should be noted include the self-report, retrospective nature of the data and the fact that interviewers were aware of the case status of the participants. Also, the matched design that was used resulted in some relatively small sample sizes, particularly for the black participants. This was due to the difficulty encountered in recruiting black PC women. It is unknown why proportionally fewer black PC women than white PC women responded to our recruitment efforts, and this will be important for future studies to consider. Finally, matching of comparison women to BED cases on body mass index (in addition to matching on age, ethnicity, and education) was not possible owing to the fact that with each matching variable the sample size requirements increase.

Limitations notwithstanding, our study adds support for the observation that there appear to be few specific risk factors for the development of BED. Together with the Oxford risk factor study our results suggests that family overeating and childhood obesity are specific risk factors for BED, and it seems that ethnicity does not moderate risk for BED. Because our study was limited to black women, studies of other ethnic minority groups are needed to gain a more complete understanding of the role of ethnicity in the development of BED.

\section{ACKNOWLEDGEMENTS}

This study was supported by NIMH grant MH-52348 and by a supplemental grant from the Office for Research on Women's Health at NIH. The authors thank Dr Sarah Welch for assisting Dr Christopher Fairburn in providing training on the Eating Disorder Examination and Risk Factor Interview and Mimi Gibbon for providing initial training on the Structured Clinical Interview for DSM-IV and annual retraining workshops.

\section{DECLARATION OF INTEREST}

None.

\section{REFERENCES}

APA (1994). Diagnostic and Statistical Manual of Mental Disorders (4th edn) (DSM-IV). American Psychiatric Association: Washington, DC.
Bradburn, N. M. (2000). Temporal representation and event dating. In The Science of Self-Report (ed. A. A. Stone, J. S. Turrkan, C. A Bachrach and H. S. Kurtzman), pp. 49-61. Lawrence Erlbaum Associates: Hillsdale, NJ

Bulik, C. M., Sullivan, P. F., Wade, T. D. \& Kendler, K. S. (2000). Twin studies of eating disorders: a review. International Journal of Eating Disorders 27, 1-20.

Carter, W. P., Hudson, J. I., Lalonde, J. K., Pindyck, L. \& Pope, H. G. (2003). Pharmacologic treatment of binge-eating disorder. International Journal of Eating Disorders 34 (Suppl.), S74-S88.

Cohen, J. (1988). Statistical Power Analysis for the Behavioral Sciences (2nd edn). Lawrence Erlbaum Associates: Hillsdale, NJ.

Cox, B. J., Enns, M. W. \& Clara, I. P. (2000). The Parental Bonding Instrument: confirmatory evidence for a three-factor model in a psychiatric clinical sample in the National Comorbidity Survey. Social Psychiatry and Psychiatric Epidemiology 35, 353-357.

Dohm, F. A. \& Striegel-Moore, R. H. (2002). The Food Amount Rating Scale: development, reliability, and validity. Obesity Research 10, 1173-1179.

Enns, M. W., Cox, B. J. \& Clara, I. P. (2002). Parental bonding and adult psychopathology: results from the US National Comorbidity Survey. Psychological Medicine 32, 997-1008.

Fairburn, C. G. \& Cooper, Z. (1993). The eating disorder examination. In Binge Eating (ed. C. G. Fairburn and G. T. Wilson), pp. 317-360. Guilford Press: New York.

Fairburn, C. G., Cooper, Z, Doll, H. A. \& Welch, S. L. (1999). Risk factors for anorexia nervosa: three integrated case-control comparisons. Archives of General Psychiatry 56, 468-476.

Fairburn, C. G., Doll, H. A., Welch, S., Hay, P. J., Davies, B. A. \& O'Connor, M. E. (1998). Risk factors for binge-eating disorder: a community-based, case-control study. Archives of General Psychiatry 55, 425-432.

Fairburn, C. G., Welch, S. L., Doll, H. A., Davies, B. A. \& O'Connor, M. E. (1997). Risk factors for bulimia nervosa: a communitybased case-control study. Archives of General Psychiatry 54, 509-517.

Fairburn, C. G., Welch, S. L., Norman, P. A., O'Connor, M. E. \& Doll, H. A. (1996). Bias and bulimia nervosa: how typical are clinic cases? American Journal of Psychiatry 153, 386-391.

First, M. B., Spitzer, R. L., Gibbon, M. A. \& Williams, J. B. (1996). Structured Clinical Interview for DSM-IV Axis I DisordersNon-Patient Edition. New York State Psychiatric Institute: New York.

Halmi, K. A., Sunday, S. R., Strober, M., Kaplan, A., Woodside, D. B., Fichter, M., Treasure, J., Berrettini, W. H. \& Kaye, W. H. (2000). Perfectionism in anorexia nervosa: variation by clinical subtype, obsessionality, and pathological eating behavior. American Journal of Psychiatry 157, 1799-1805.

Johnson, J. G., Spitzer, R. L. \& William, J. B. (2001). Health problems, impairment and illnesses associated with bulimia nervosa and binge-eating disorder among primary care and obstetric gynecology patients. Psychological Medicine 3, 1455-1466.

Kendler, K. S., Walters, E. E., Neale, M. C., Kessler, R. C., Heath, A. C. \& Eaves, L. J. (1995). The structure of the genetic and environmental risk factors for six major psychiatric disorders in women. Archives of General Psychiatry 52, 374-383.

Kessler, R. C., Davis, C. G. \& Kendler, K. S. (1997). Childhood adversity and adult psychiatric disorder in the U.S. National Comorbidity Survey. Psychological Medicine 27, 1101-1119.

Kraemer, H. C., Kazdin, A. E., Offord, D. R., Kessler, R. C., Jensen, P.S. \& Kupfer, D. J. (1997). Coming to terms with the terms of risk. Archives of General Psychiatry 54, 337-343.

Lilenfeld, L. R., Stein, D., Bulik, C. M., Strober, M., Plotnicov, K., Pollice, C., Rao, R., Merikangas, K. R., Nagy, L. \& Kaye, W. H. (2000). Personality traits among current eating disordered, recovered and never ill first-degree female relatives of bulimic and control women. Psychological Medicine 30, 1399-1410.

Parker, G., Tupling, H. \& Brown, L. B. (1979). A parental bonding instrument. British Journal of Medical Psychology 52, 1-10.

Pike, K. M., Dohm, F. A., Striegel-Moore, R. H., Wilfley, D. E., Pike, K. M. \& Fairburn, C. G. (2001). A comparison of Black and White 
women with binge-eating disorder. American Journal of Psychiatry 158, 1455-1460.

Reti, I. M., Samuels, J. F., Eaton, W. W., Bienvenu, J. O., Costa, P. T. \& Nestad, G. (2002). Influences of parenting on normal personality traits. Psychiatry Research 111, 55-64.

Rizvi, S. L., Peterson, C. B., Crox, S. J. \& Agras, W. S. (2000). Testretest reliability of the eating disorder examination. International Journal of Eating Disorders 28, 311-316.

Sanchez-Johnsen, L. A., Fitzgibbon, M. L., Martinovich, Z., Stolley, M. D., Dyer, A. R. \& van Horn, L. (2004). Ethnic differences in correlates of obesity between Latin-American and Black women. Obesity Research 12, 652-660.

Segal, D. L., Hersen, M. \& Van Hasselt, V. B. (1994). Reliability of the structured clinical interview for DSM III-R: an evaluative review. Comprehensive Psychiatry 35, 316-327.

Smith, D. E., Marcus, M. D., Lewis, C. E., Fitzgibbon, M. \& Schreiner, P. (1998). Prevalence of binge-eating disorder, obesity, and depression in a biracial cohort of young adults. Annals of Behavioral Medicine 20, 227-232.

Smolak, L. \& Striegel-Moore, R. H. (2001). Challenging the myth of the golden girl: ethnicity and eating disorders. In Eating Disorders: Innovative Directions in Research and Practice (ed. R. H. StriegelMoore and L. Smolak), pp. 111-132. American Psychological Association: Washington, DC.

Sorensen, T. I. \& Stunkard, A. J. (1993). Does obesity run in families because of genes? An adoption study using silhouettes as a measure of obesity. Acta Psychiatrica Scandinavia 370 (Suppl.), $67-72$.

Striegel-Moore, R. H. \& Cachelin, F. M. (2001). Etiology of eating disorders in women. Journal of Counseling Psychology 29, 635-661.
Striegel-Moore, R. H., Dohm, F. A., Kraemer, H. C., Taylor, C. B., Daniels, S. R., Crawford, P. B. \& Schreiber, G. (2003). Eating disorders in black and white young women. American Journal of Psychiatry 160, 1326-1331.

Striegel-Moore, R. H., Dohm, F. A., Pike, K. M., Wilfley, D. E. \& Fairburn, C. G. (2002). Abuse, bullying and discrimination as risk factors for binge-eating disorder. American Journal of Psychiatry 159, 1902-1907.

Striegel-Moore, R. H., Silberstein, L. R. \& Rodin, J. (1986). Toward an understanding of risk factors for bulimia. American Psychologist 41, 246-263.

Striegel-Moore, R. H., Wilfley, D. E., Pike, K. M., Dohm, F. A. \& Fairburn, C. G. (2000). Recurrent binge eating in Black American women. Archives of Family Medicine 9, 83-87.

Sullivan, P. F., Bulik, C. M. \& Kendler, K. S. (1998). Genetic epidemiology of binging and vomiting. British Journal of Psychiatry 173, 75-79.

Wilfley, D. E., Pike, K. M., Dohm, F. A., Striegel-Moore, R. H. \& Fairburn, C. G. (2001). Bias in binge-eating disorder: how representative are recruited clinic samples? Journal of Consulting \& Clinical Psychology 69, 383-388.

Wilfley, D. E., Pike, K. M. \& Striegel-Moore, R. H. (1997). Toward an integrated model of risk for binge-eating disorder. Journal of Gender, Culture \& Health 2, 1-32.

Wilfley, D. E., Wilson, T. \& Agras, S. (2003). The clinical significance of binge-eating disorder. International Journal of Eating Disorders 34 (Suppl.), S96-S106.

Wonderlich, S. A., de Zwaan, M., Mitchell, J. E., Peterson, C. \& Crow, S. (2003). Psychological and dietary treatments of bingeeating disorder: conceptual implications. International Journal of Eating Disorders 34 (Suppl.), S58-S73. 
Reproduced with permission of the copyright owner. Further reproduction prohibited without permission. 